International Journal of Physical Research, $9(1)(2021) 56-59$
SPC
Website: $w w w . s c i e n c e p u b c o . c o m / i n d e x . p h p / I J P R$
Research paper

\title{
Concentrations and health risks assessment of heavy metals in cigarettes within Baghdad city
}

\author{
Azhar M Haleem, Sahar A Amin \\ Environment Research Center, University of Technology Baghdad, Iraq
}

\begin{abstract}
The risks associated with smoking can be due to the inhalation of toxic substances like heavy metals and polycyclic aromatic hydrocarbons (PAHs) that can be released during tobacco burns. In the present study we measured lead $\mathrm{Pb}$ and three other metals (cadmium Cd; Chrome $\mathrm{Cr}$; and Zinc Zn) by flame atomic absorption spectroscopy (FAAS). In a twenty-five brands of cigarettes, assessing potential related health risks estimated intakes of these metals. The Related Cancer Risk (RCR) and Average Daily Intake (ADI) were calculated. The results revealed that the average values of $\mathrm{Pb}, \mathrm{Cd}, \mathrm{Cr}$ and $\mathrm{Zn}$ concentrations were $(4.56,0.39,3.31$ and 1.36$) \mu \mathrm{g} / \mathrm{g}$ respectively. The total value of these four metals is greater than the range of cancer risk specified by USEPA.
\end{abstract}

Keywords: Use about five key words or phrases in alphabetical order, Separated by Semicolon

\section{Introduction}

Smoking kills one person among ten around the world [1]. There are about 1.1 billion smokers; their proportion varies between women and men. Generally, the ratio is distributed between $30 \%$ for women and $70 \%$ for men [2]. Tobacco contains more than 6000 toxic compounds which are released during the smoking process and they cause significant risks for a variety of respiratory and cardiovascular diseases and developing cancers. These compounds include heavy metals such as lead, cadmium, copper, arsenic and nickel besides polycyclic aromatic hydrocarbons (PAHs) like Benzo[a]pyrene that are characterized as strong carcinogenic for humans [3].

Exposing metals due to smoking of a single cigarette can be trivial and likely not severely toxic, but the accumulated of the inhaled amount of metals in the body during long period of time (months, years and decades) of exposure depends on clearance rates and health concern [4 and 5] Many heavy metals like $\mathrm{Cd}, \mathrm{Ni}, \mathrm{Pb}$ and $\mathrm{Cr}$ can accumulate in organ tissues after smoking [6-9], especially for $\mathrm{Cd}$ and $\mathrm{Pb}$ which have long half-lives between 10 to 12 year in the human body. Cigarette smoking can be considered the main exposure access for Cd and to a lower range $\mathrm{Pb}$ in the general population [8 and 9].

Lead $(\mathrm{Pb})$ and cadmium $(\mathrm{Cd})$ have unknown biological functions in humans, and have toxicity even at low concentrations. Furthermore, $\mathrm{Pb}$ and $\mathrm{Cd}$ are known as pollutants, while $\mathrm{Cd}$ and $\mathrm{Cr}$ are classified as carcinogenic and causes multiple disorders such as cardiovascular diseases, liver diseases, neurotoxic, and nephrotoxic making $\mathrm{Cd}$ and $\mathrm{Cr}$ a global concern [10].

In this study which was carried out in January-2019, in the Environmental Research Center, University of Technology, Baghdad, Iraq, twenty four brands of imported cigarettes from seven different origins and one local brand (USA, UK, Korea, Turkey, France, Switzerland and Iraq) were collected randomly from the markets in order to determine heavy metals concentration utilizing flame atomic absorption spectroscopy (FAAS). The investigated heavy metals were (lead $(\mathrm{Pb})$, Cadmium $(\mathrm{Cd})$, Chrome $(\mathrm{Cr})$ and $\mathrm{Zinc}(\mathrm{Zn})$ and assess the human health risk through chronic consumption of tobacco

\section{Materials and methods}

\subsection{Sample preparation and heavy metals analyses}

The contents of each pack were emptied in the laboratory by removing cigarette papers and filters. Then tobacco samples were pulverized by ceramic mortar. $5 \mathrm{gm}$ of tobacco powder of each brand sample was added to $25 \mathrm{~mL}$ of concentrated HNO3, then mixed well and put on a hot plate and left to dry [11]. The remainder of the mixture was filtered through 0.45 Millipore filter paper and completes the volume to $10 \mathrm{ml}$ using a volumetric flask with deionized water. Then the heavy metals concentration was analyzed using flame atomic absorption spectrophotometer (FAAS).

\subsection{Assessment of lifetime cancer risk}


Cancer power factors $(\mathrm{CPF})((\mathrm{mg} / \mathrm{kg}$ body-weight/day) -1$)$ for the toxic heavy metals $(\mathrm{Pb}, \mathrm{Cd}, \mathrm{Cr}$, and $\mathrm{Zn})$ were calculated for both ingestion and inhalation processes of the tobacco consumption on a long-term basis. Lifetime cancer risk (LCR) due to tobacco products was determined by using equation number (1) [12].

$$
\mathrm{LCR}=\mathrm{MDE} \times \frac{\text { Years of consumption. }}{\text { Mean lifetime }} \times \mathrm{CPF}
$$

Where (MDE) is the mean daily exposure ( $\mathrm{mg} / \mathrm{kg}$ body-weight/day) which was calculated assuming the daily consumption of $10 \mathrm{gm}$ of tobacco by a person with a body weight of $57.7 \mathrm{~kg}$ for 30 years out of an average lifetime of 70 years.

\section{Results and discussion}

Figures (1-4) summarized the concentrations of $\mathrm{Pb}, \mathrm{Cd}, \mathrm{Cr}$, and $\mathrm{Zn}$ for the tobacco brands. lead values ranged from (1.235-9.260) $\mu \mathrm{g} / \mathrm{g}$ with an average value of $4.563 \mu \mathrm{g} / \mathrm{g}$. C19 recorded the highest concentration value of $\mathrm{Pb}$ while $\mathrm{C} 11$ recorded lowest concentration value with significant differences at $(\mathrm{p} \leq 0.05)$ as shown in Figure 1. Figure 2 illustrates the concentrations of $\mathrm{Cd}$ which were ranged from the lowest value of ND in C1 and C20 samples to the highest value of (1.559) $\mu \mathrm{g} / \mathrm{g}$ in C15 with an average value of $0.3986 \mu \mathrm{g} / \mathrm{g}$ with significant differences at $(\mathrm{p} \leq 0.05)$. Figure 3 shows the concentration of $\mathrm{Cd}$ element, the values of $\mathrm{Cd}$ in study samples were ranged from ND value found in C5, C7 and C13 samples while the highest value of $\mathrm{Cr}$ concentration was found in $\mathrm{C} 23$ sample with value of $(6.725) \mu \mathrm{g} / \mathrm{g}$, and the average value was $(3.31) \mu \mathrm{g} / \mathrm{g}$, with significant differences at $(\mathrm{p} \leq 0.05)$. Finally, Figure 4 shows the concentrations of $\mathrm{Zn}$ which were ranged from (0.167- 3.112) $\mu \mathrm{g} / \mathrm{g}$ with average $1.369 \mu \mathrm{g} / \mathrm{g}, \mathrm{Zn}$ recorded highest level in C21 Sample while the lowest level was in C17 Sample, with significant differences at $(\mathrm{p} \leq 0.05)$. Sample $\mathrm{C} 20$ was found to contain the highest total amount of heavy metals with the value of (18.937) $\mu \mathrm{g} / \mathrm{g}$ while C13 recorded the lowest total content of heavy metals with the value of $(4.821) \mu \mathrm{g} / \mathrm{g}$. The concentrations of the heavy metals varied considerably among different brands. Actually, the differences in heavy metal content could possibly be related to soil type, water contents of trace elements, growth conditions, and tobacco type and tobacco treatment process.

Comparison of the presents results obtained in this study with previous studies is shown in Table (1) the results are found to be comparable with others results.

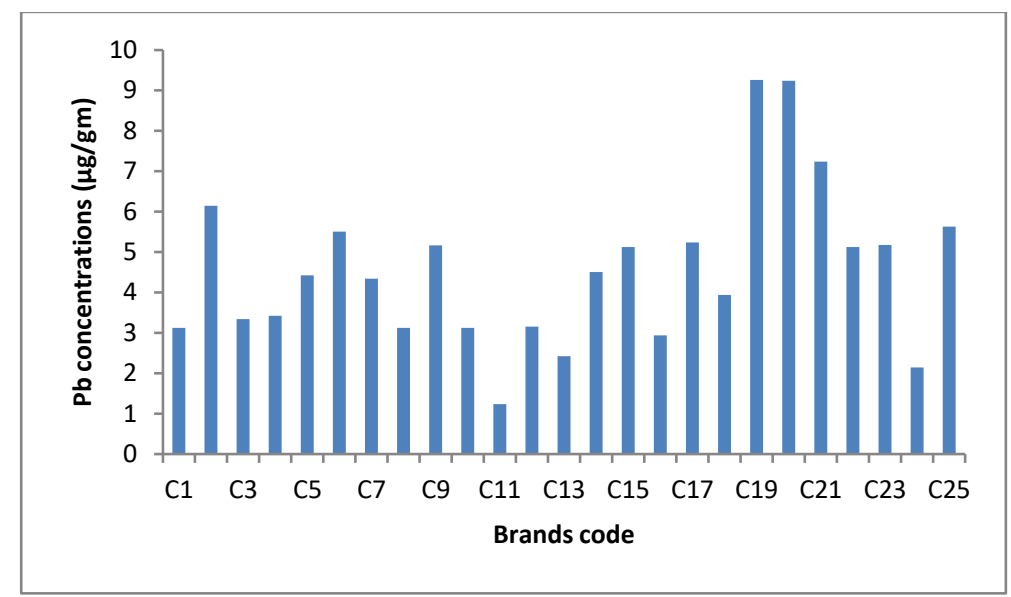

Fig. 1: $\mathrm{Pb}$ Concentrations in Tobacco Samples.

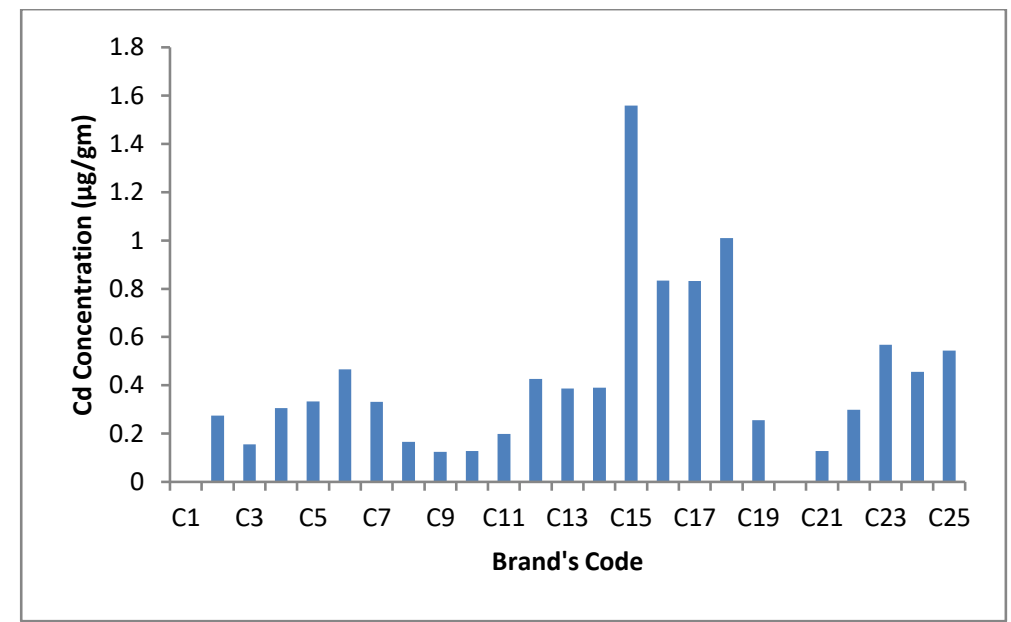

Fig. 2: Cd Concentrations in Tobacco Samples. 


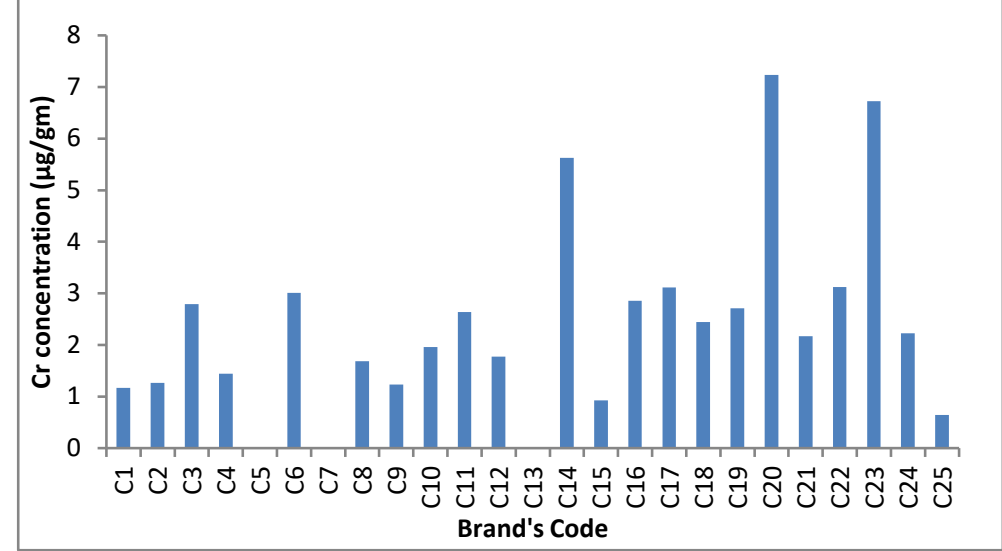

Fig. 3: Cr Concentrations in Tobacco Samples.



Fig. 4: Zn Concentrations in Tobacco Samples.

Table 1: Heavy Metal Concentrations $(\mathrm{Mg} / \mathrm{G})$ in Tobacco Cigarettes Compared with Previous Studies

\begin{tabular}{|c|c|c|c|c|}
\hline $\mathrm{Pb}$ & $\mathrm{Cd}$ & $\mathrm{Cr}$ & $\mathrm{Zn}$ & Ref. \\
\hline $1.33-3.61$ & $0.78-2.78$ & ------ & ------ & [13] \\
\hline $1.07-2.54,1.77$ & $0.91-3.46,2.01$ & $1.08-6.75,2.26$ & ------ & [12] \\
\hline $7.50-32.50$ & $1.82-5.40$ & ----- - & ------ & [14] \\
\hline $0.6-2.00,2.40$ & $0.5-3.5,1.70$ & $0.1-3.45$ & $16.8-30.5$ & [15] \\
\hline 0.44 & 0.86 & 2.35 & ------ & [16] \\
\hline $1.24-9.26,4.56$ & ND-1.56, 0.40 & ND-6.73, 3.32 & $0.17-3.11,1.37$ & Present work \\
\hline
\end{tabular}

$\mathrm{ND}=$ Not detected

Table 2: CPF Values ((Mg/Kg Body-Weight/Day $\left.)^{-1}\right)$ As Described by California Environmental Protection Agency (CEPA 2009)

\begin{tabular}{llll}
\hline $\mathrm{Pb}$ & $\mathrm{Cd}$ & $\mathrm{Cr}$ & $\mathrm{Zn}$ \\
\hline $8.3 \times 10^{-3}$ & 15 & 0.42 & 0.2 \\
\hline
\end{tabular}

The method of estimating potential toxicity assumes that $100 \%$ of the toxicant is potentially bio-available in ideal conditions and can fully contribute to the overall risk of the product [17-20]. In this study, $57.7 \mathrm{~kg}$ body weight was considered as the body weight of an Asian adult [21] and daily tobacco consumption data was collected from the report on Global adult tobacco survey by [22]. The toxicological risk calculated as a cancer risk for $\mathrm{Pb}, \mathrm{Cd}, \mathrm{Cr}$, and $\mathrm{Zn}$ at a transfer rate of $100 \%$ are presented in Table (3). The risk of individual metal for the study samples ranges from $9.96 \times 10-6$ to $1.05 \times 10-6$ for $\mathrm{Pb}$, from $9.25 \times 10-4$ to $1.11 \times 10-3$ for $\mathrm{Cd}$, from $\mathrm{ND}$ to $1.13 \times 10-3 \mathrm{for} \mathrm{Cr}$, and from $8.14 \times 10-5$ to $2.31 \times 10-4$ for $\mathrm{Zn}$. The total value of these four metals is greater than the range of cancer risk compared with the limit value of $10 \times 10-4$ to $10 \times 10-6$ specified by [23].

Table 3: Lifetime Cancer Risk of the Tobacco Consumption on A Long-Term Basis

\begin{tabular}{|c|c|c|c|c|c|}
\hline Brand's Code & $\mathrm{Pb}$ & $\mathrm{Cd}$ & $\mathrm{Cr}$ & $\mathrm{Zn}$ & Total value \\
\hline $\mathrm{C} 1$ & $9.86 \times 10^{-6}$ & ND & $1.82 \times 10^{-4}$ & $1.67 \times 10^{-4}$ & $3.59 \times 10^{-4}$ \\
\hline $\mathrm{C} 2$ & $1.94 \times 10^{-5}$ & $1.53 \times 10^{-3}$ & $1.98 \times 10^{-4}$ & $3.14 \times 10^{-5}$ & $17.75 \times 10^{-4}$ \\
\hline C3 & $1.05 \times 10^{-5}$ & $8.63 \times 10^{-4}$ & $4.35 \times 10^{-4}$ & $5.84 \times 10^{-5}$ & $13.67 \times 10^{-4}$ \\
\hline $\mathrm{C} 4$ & $1.08 \times 10^{-5}$ & $1.71 \times 10^{-3}$ & $2.25 \times 10^{-4}$ & $5.76 \times 10^{-5}$ & $19.98 \times 10^{-4}$ \\
\hline C5 & $1.40 \times 10^{-5}$ & $1.86 \times 10^{-3}$ & ND & $6.59 \times 10^{-5}$ & $19.4 \times 10^{-4}$ \\
\hline C6 & $1.74 \times 10^{-5}$ & $2.60 \times 10^{-3}$ & $4.70 \times 10^{-4}$ & $3.45 \times 10^{-5}$ & $31.18 \times 10^{-4}$ \\
\hline $\mathrm{C} 7$ & $1.37 \times 10^{-5}$ & $1.85 \times 10^{-3}$ & ND & $2.73 \times 10^{-5}$ & $18.9 \times 10^{-4}$ \\
\hline $\mathrm{C} 8$ & $9.86 \times 10^{-6}$ & $9.25 \times 10^{-4}$ & $2.63 \times 10^{-4}$ & $7.97 \times 10^{-5}$ & $12.77 \times 10^{-4}$ \\
\hline C9 & $1.63 \times 10^{-5}$ & $6.96 \times 10^{-4}$ & $1.92 \times 10^{-4}$ & $8.01 \times 10^{-5}$ & $9.85 \times 10^{-4}$ \\
\hline $\mathrm{C} 10$ & $9.85 \times 10^{-6}$ & $7.13 \times 10^{-4}$ & $3.05 \times 10^{-4}$ & $2.21 \times 10^{-4}$ & $12.49 \times 10^{-4}$ \\
\hline $\mathrm{C} 11$ & $3.90 \times 10^{-6}$ & $1.11 \times 10^{-3}$ & $4.11 \times 10^{-4}$ & $1.09 \times 10^{-4}$ & $16.32 \times 10^{-4}$ \\
\hline $\mathrm{C} 12$ & $9.96 \times 10^{-6}$ & $2.37 \times 10^{-3}$ & $2.77 \times 10^{-4}$ & $1.57 \times 10^{-4}$ & $28.17 \times 10^{-4}$ \\
\hline $\mathrm{C} 13$ & $7.65 \times 10^{-6}$ & $2.16 \times 10^{-3}$ & ND & $1.49 \times 10^{-4}$ & $23.13 \times 10^{-4}$ \\
\hline $\mathrm{C} 14$ & $1.42 \times 10^{-5}$ & $2.18 \times 10^{-3}$ & $8.78 \times 10^{-4}$ & $1.16 \times 10^{-4}$ & $31.87 \times 10^{-4}$ \\
\hline
\end{tabular}




\begin{tabular}{|c|c|c|c|c|c|}
\hline C15 & $1.62 \times 10^{-5}$ & $8.69 \times 10^{-3}$ & $1.44 \times 10^{-4}$ & $5.70 \times 10^{-5}$ & $89.02 \times 10^{-4}$ \\
\hline $\mathrm{C} 16$ & $9.26 \times 10^{-6}$ & $4.64 \times 10^{-3}$ & $4.45 \times 10^{-4}$ & $1.57 \times 10^{-4}$ & $52.52 \times 10^{-4}$ \\
\hline $\mathrm{C} 17$ & $1.65 \times 10^{-5}$ & $4.64 \times 10^{-3}$ & $4.89 \times 10^{-4}$ & $1.24 \times 10^{-5}$ & $51.50 \times 10^{-4}$ \\
\hline C18 & $1.24 \times 10^{-5}$ & $5.63 \times 10^{-3}$ & $3.81 \times 10^{-4}$ & $3.38 \times 10^{-5}$ & $60.54 \times 10^{-4}$ \\
\hline C19 & $2.92 \times 10^{-5}$ & $1.43 \times 10^{-3}$ & $4.23 \times 10^{-4}$ & $1.28 \times 10^{-4}$ & $20.06 \times 10^{-4}$ \\
\hline $\mathrm{C} 20$ & $2.92 \times 10^{-5}$ & ND & $1.13 \times 10^{-3}$ & $1.83 \times 10^{-4}$ & $13.41 \times 10^{-4}$ \\
\hline $\mathrm{C} 21$ & $2.28 \times 10^{-5}$ & $7.13 \times 10^{-4}$ & $3.38 \times 10^{-4}$ & $2.31 \times 10^{-4}$ & $13.05 \times 10^{-4}$ \\
\hline $\mathrm{C} 22$ & $1.62 \times 10^{-5}$ & $1.66 \times 10^{-3}$ & $4.87 \times 10^{-4}$ & $1.57 \times 10^{-4}$ & $23.21 \times 10^{-4}$ \\
\hline $\mathrm{C} 23$ & $1.63 \times 10^{-5}$ & $3.16 \times 10^{-3}$ & $1.05 \times 10^{-3}$ & $7.49 \times 10^{-5}$ & $43.04 \times 10^{-4}$ \\
\hline $\mathrm{C} 24$ & $6.77 \times 10^{-6}$ & $2.54 \times 10^{-3}$ & $3.48 \times 10^{-4}$ & $8.14 \times 10^{-5}$ & $29.76 \times 10^{-4}$ \\
\hline $\mathrm{C} 25$ & $1.78 \times 10^{-5}$ & $3.03 \times 10^{-3}$ & $1.01 \times 10^{-4}$ & $7.29 \times 10^{-5}$ & $32.16 \times 10^{-4}$ \\
\hline
\end{tabular}

$\mathrm{ND}=$ Not detected

\section{Conclusions}

Smoking of cigarettes may be concerned as an essential cause of inhalation of the highly toxic elements not only to the smoker but also, through passive smoking, to nonsmokers. They also have a reverse health effects on the fetus through maternal smoking, and on infants through parental smoking.

The results of this study provide an overview of four heavy metal concentrations $(\mathrm{Pb}, \mathrm{Cd}, \mathrm{Cr}$, and $\mathrm{Zn})$ measured in tobacco products. From the results, we concluded that all tobacco products contain a high level of the four measured heavy metals. The cancer risk, which is based on the consumer's practice, bodyweight, lifetime, availability and exposure to the metals, has also been assessed. The results show that the total value of these four metals is greater than the range of cancer risk specified by USEPA (1989).

\section{References}

[1] World Health Organization 2013 Tobacco fact sheet No 339. Updated July 2013. Available at: http://www. who.int/mediacentre/factsheets/fs339/en/ (Accessed: 18 November 2013).

[2] Smitha CJ, Perfettia TA, Gargb R, Hanschb C 2003 IARC carcinogens reported in cigarette mainstream smoke and their calculated log P values. Food and Chemical Toxicology 41, 807-817. https://doi.org/10.1016/S0278-6915(03)00021-8.

[3] Viana GF, Garcia KS, Menezes-Filho JA 2011 Assessment of carcinogenic heavy metals in Brazilian cigarettes. Environ Monit Assess 181, 255265. https://doi.org/10.1007/s10661-010-1827-3.

[4] Caruso RV, O'Connor RJ, Stephens WE 2013 Toxic Metal Concentrations in Cigarettes Obtained from the U.S. Smokers in 2009: Results from the International Control (ITC) United States Survey Cohort. Int J Environ Res Public Health: 10. https://doi.org/10.3390/ijerph110100202.

[5] Omari MO, Kibet JK, Cherutoi JK, Bosire JO, Rono NK 2015 Heavy Metal Content in Mainstream Cigarette Smoke of Common Cigarettes Sold in Kenya, and their Toxicological Consequences, International Research Journal of Environment Sciences. 4(6), 75-79.

[6] Stojanović, D, Nikić, D, Lazarević K 2004 The level of nickel in smoker's blood and urine. Cent. Eur.J. Public Health. 12, 187-189.

[7] Galazyn SM, Brzóska MM, Moniuszko JJ 2008 Estimation of Polish cigarettes contamination with cadmium and lead, and exposure to these metals via smoking. Environ. Monit.Assess. 137, 481-493. https://doi.org/10.1007/s10661-007-9783-2.

[8] Richter PA, Bishop EE, Wang J, Swahn MH 2009 Tobacco smoke exposure and levels ofurinary metals in the U.S. youth and adult population: the National Health and Nutrition Examination Survey (NHANES) 1999-2004. Int. J. Environ. Res. Public Health. 6, $1930-1946$. https://doi.org/10.1007/s10661-007-9783-2.

[9] Tellez PM, Navas AA, Caldwell KL, Menke A, Muntner P, Guallar E 2012 Reduction in cadmium exposure in the United States population, 19882008: The contribution of declining smoking rates. Environ. Health Perspect 120, 204-209. https://doi.org/10.1289/ehp.1104020.

[10] Agency for toxic substances and disease registry (ATSDR) 2012 Toxicological Profile for Cadmium, U.S. Department 433 of Health and Human Services, Public Health Service. https://www.atsdr.cdc.gov/toxprofiles/tp.asp?id=48\&tid=15.

[11] Elinder CG, Kjellstrom T, Lind B Linnman I, Piscator M, Sundstedt K 1983 Cadmium exposure from smoking cigarette, variations with times and country where purchased, Environ Res. 32(1): 220-227. https://doi.org/10.1016/0013-9351(83)90209-8.

[12] Hossain TM, Hassi U, Imamu SM 2018 Assessment of concentration and toxicological (Cancer) risk of lead, cadmium and chromium in tobacco products commonly available in Bangladesh, Toxicology Reports, 5: Pages 897-902. https://doi.org/10.1016/j.toxrep.2018.08.019.

[13] Ashraf MW 2012 Levels of HeavyMetals in Popular Cigarette Brands and Exposure to TheseMetals via Smoking, the Scientific World Journal, Volume, Article ID 729430, 5. https://doi.org/10.1100/2012/729430.

[14] Ziarati P, Mousavi Z, Pashapour S 2017 Analysis of Heavy Metals in Cigarette Tobacco, Journal of Medical Discovery. 2(1): jmd16006; https://doi.org/10.24262/jmd.2.1.16006.

[15] Chiba, Momoko \& Masironi, Roberto 1992 Toxic and trace elements in tobacco and tobacco smoke / M. Chiba \& R. Masironi. Bulletin of the World Health Organization 1992; 70((2.275-269 : https://apps.who.int/iris/handle/10665/49331.

[16] Caruso RV, Richard J. O'Connor W, Edryd Stephens E, Cummings M, Geoffrey TF 2014 Toxic Metal Concentrations in Cigarettes Obtained from U.S. Smokers in 2009: Results from the International Tobacco Control (ITC) United States Survey Cohort, International Journal of Environmental Research and Public Health, 11, 202-217. https://doi.org/10.3390/ijerph110100202.

[17] California Environmental Protection Agency (CEPA) 2009 Technical Support Document for Cancer potency Factors: Methodologies for Derivation, Listing of Available Values and Adjustments to Allow for Early Life Stage Exposures: Appendix- a. https://oehha.ca.gov/media/downloads/crnr/tsdcancerpotency.pdf.

[18] Fowles J and Dybing E 2003 Application of toxicological risk assessment principles to the chemical constituents of cigarette smoke, Tob. Control 12 (4) (2003) 424-430. https://doi.org/10.1136/tc.12.4.424

[19] Pankow JF, Watanabe KH, P.L. Toccalino PL, et al. 2007 Calculated cancer risks for conventional and "potentially reduced exposure product" cigarettes, Cancer Epidemiol. Biomarkers Prev. 16 (3) 584-592. https://doi.org/10.1158/1055-9965.EPI-06-0762.

[20] Haleem AM, Amin SA, Mahmood UH 2020 Heavy metal and polycyclic aromatic hydrocarbons in cigarettes: An analytical assessment. Popul. Med. 2020;2(June):19. https://doi.org/10.18332/popmed/122558.

[21] Sarah CW, Prieto-Merino D, Edwards P, Cleland J, Stevens G, Roberts I. (2012). The weight of nations: an estimation of adult human biomass, BMC Public Health. 12: 439. https://doi.org/10.1186/1471-2458-12-439.

[22] World Health Organization (WHO) 2009 Global Adult Tobacco Survey: Bangladesh Report, Country Office for Bangladesh Ministry of Health and Family Welfare, Government of the People's Republic of Bangladesh. http://www.searo.who.int/bangladesh/publications/gats_2009/en/

[23] United States Environmental Protection Agency (USEPA) 1989 Washington, D.C (1989), 20450, Risk Assessment Guidance for Superfund Volume I Human Health Evaluation Manual: Part A. https://www.epa.gov/sites/production/files/2015-09/documents/rags_a.pdF. 